\title{
Teacher Performance:
}

\author{
Gender and Education Status in Teacher Certification Perspective
}

\author{
Maryah Sariningsih*, Aan Komariah \\ Educational Administration Department \\ Universitas Pendidikan Indonesia \\ Bandung, Indonesia \\ *msariningsih03@gmail.com
}

\begin{abstract}
A number of studies have shown that teacher professional allowance (certification) does not have a positive impact on the teacher own performance. This research seeks to dig deeper into this by looking at teacher gender and education level. Data is obtained from secondary data collected from Dapodik data of Purwakarta District Education Office. Through purposive sampling techniques, 167 respondents were obtained, consisting of 51 male teachers and 116 female teachers. From the respondents also obtained the distribution of education of each teacher. 131 undergraduate teachers and 36 master's graduates. Data processing techniques use an independent sample test approach to test the difference between female and male teachers who are certified in terms of performance, as well as from the level of education they have. The results showed that gender differences and levels of education in performance results did not have significant differences. The level of education does not affect performance outcomes. Similarly, the differences between the sexes of women and men do not provide a difference in performance results.
\end{abstract}

Keywords-gender, teacher education degree, teacher certification, teacher performance

\section{INTRODUCTION}

The low competitiveness of a nation can be caused by the low quality of education of the nation, so that the output of education is not able to win the competition in the world of work and the world of business. Less competitive educational output can be caused by the less than optimal capacity of educational units in transforming students to obtain added value. The main actor in the process of transforming added value to students is the teacher. Therefore, teachers can be said to hold a very important and strategic role in efforts to improve the quality of education in each education unit. Regardless of the amount of investment invested to improve the quality of education, without the presence of competent, professional, dignified and prosperous teachers, it is certain that the expected goals will not be achieved.

The results of research found that only $37 \%$ of certified teachers can convey material clearly, the ability to use media and learning technology, the ability to follow science and technology developments and learning innovations and sustainable professional development still need to be improved. In this study, it was also revealed that certified teachers had not shown a significant increase in the quality of learning in the classroom. This is indicated by the inadequate ability to explain the material, the lack of ability to utilize learning technology (around 25\% stated that it is insufficient) and 20\% of the teachers indicated that they did not pay attention to the situation of individual students [1].

Furthermore, the results of research conducted by Ramdhani et al., show that the provision of allowances or incentives obtained from teacher certification in several schools has led to changes in social behavior between teachers who received incentives and teachers who did not receive incentives [2]. Teacher certification also affects economic behavior in the teaching profession, both in public and private schools, as seen by the increase in their welfare.

In improving the quality and performance of teachers, starting in 2007 the government (Depdiknas) conducted competency tests for teachers. Teachers who have met the certification criteria are given the opportunity to take part in a series of competency examination processes to obtain a teacher certificate. Certification for pre-service teachers is carried out through teacher professional education (PPG) at an accredited and designated LPTK, ending with a competency test.

In-service teacher certification is carried out in accordance with the Regulation of the Minister of Education and Culture Number 05 of 2012, which is carried out in the form of portfolio assessment, teacher professional education and training, direct issuance of teacher certificates, and through teacher professional education.

Teachers in Indonesia must respond to certification as a process that can support teachers' abilities to be more professional. This professional attitude is expected to arise after the teacher has passed the certification test. Another hope for this certification is that it can realize the standards and quality of education in Indonesia that are equal to education in other countries. With teacher certification, it is hoped that it will improve student achievement. Based on the research results, teachers who are certified and who have an educational 
background in accordance with what they teach in class are related to student achievement [3].

Certification is the process of giving certificates to teachers who have met certain requirements, namely having academic qualifications, competence, being physically and mentally healthy, and having the ability to realize the goals of national education, which is accompanied by an increase in proper welfare [4]. Certification for teachers in office as an effort to improve teacher quality is expected to improve the quality of education in formal education units on an ongoing basis.

Research that examines the impact of teacher certification on performance based on gender and teacher education level has not been done much. There are many studies that dig in general and do not refer to specifics. Although this needs to be reviewed considering that male and female teachers have different characters so that in performance of course this can be different. The higher the level of teacher education is ideally correlated with the high performance shown, especially for certified teachers. So, in this case, researchers consider why research that focuses on gender differences and education levels needs to be done.

The level of education and gender of teachers has an impact on students and the performance shown in schools. The results of the study that gender differences in teachers give rise to different interactions to students. The findings found that male teachers and female teachers tended to interact more intensely with female learners compared to male learners. Research presented by teachers impacted on differences in the way students scored their learning achievement. Gender and education are two elements inherent in individuals that influence a person's behavior and way of acting, including teachers in teaching [5].

\section{MethodS}

This research uses a descriptive quantitative approach. The results of the data are obtained from the results of the teacher performance assessment in 2019 against certified elementary school teachers. Through purposive sampling techniques, 167 respondents were obtained, consisting of 51 male teachers and 116 female teachers. From the respondents also obtained the distribution of education of each teacher. 131 undergraduate teachers and 36 master's graduates. Data processing techniques use independent sample test techniques, which are to compare teacher performance scores between the sexes as well as the level of education. So, in this study, the hypothesis proposed by researchers is that there is a difference between the gender and education level of certified teachers in performance achievement.

\section{RESULTS AND DISCUSSION}

The achievement of teacher performance results is important information for education managers, as well as a quality parameter of the education process in schools. The quality of education is reflected in the learning activities that teachers do in transferring knowledge, attitude formation, and skills through meaningful learning experience in students. Performance is closely related to an individual's profile, such as gender, educational status, experience, age, religion, as well as the personality of the teacher himself. What is attached to the teacher is actually an internal factor that is still minimal in the study of education, but has a significant impact on the resulting performance.

In this study, the teacher profile was viewed from two aspects, namely gender and education level, through independent sample test analysis techniques, to obtain average performance achievement. The following are presented the results of processing the data.

TABLE I. INDEPENDENT SAMPLES TEST (GENDER)

\begin{tabular}{|c|c|c|c|c|c|c|c|c|}
\hline & \multicolumn{7}{|c|}{ Levene's Test for Equality of Variances } \\
\hline & & $F$ & Sig. & $t$ & $d f$ & Sig. (2-Tailed) & Mean Difference & Std Errir Difference \\
\hline \multirow[t]{2}{*}{ Teacher PErformance } & equal variances assumed & 2.715 & .101 & -574 & 165 & .567 & -.24457 & .42631 \\
\hline & Equal variances not assumed & & & -538 & 83.009 & .592 & -.24457 & .45452 \\
\hline
\end{tabular}

The information shown in the table above is that there is no real difference between male teachers and certified female teachers. The statement is based on the value indicated in the equal variances assumed field. With a t statistic of -0.574 and sig 0.101 it can be explained that there is no difference in teacher performance by gender.
The second test was conducted to determine the difference in teacher performance based on the level of education. Whether there is a difference in performance achievement between undergraduate-educated teachers with masters or vice versa. From the results of the tests conducted obtained the following results.

TABLE II. INDEPENDENT SAMPLES TEST (EDUCATION)

\begin{tabular}{|l|l|c|c|c|c|c|c|c|}
\hline \multicolumn{2}{|c|}{} & \multicolumn{9}{|c|}{ Levenes's Test for Equality of Variences } \\
\cline { 3 - 8 } & F & Sig. & t & df & Sig. (2-tailed) & Mean Difference & Std. Error Difference \\
\hline $\begin{array}{l}\text { Teacher } \\
\text { Performance }\end{array}$ & $\begin{array}{l}\text { Equal variances } \\
\text { assumed }\end{array}$ & 2.504 & .479 & .523 & 165 & .602 & .24975 \\
\hline & $\begin{array}{l}\text { Equal variances not } \\
\text { assumed }\end{array}$ & & & .561 & 61.941 & .577 & .47756 \\
\hline
\end{tabular}


The test results as shown in the table above are obtained the picture that from the level of education of certified teachers, there is no difference in achievement between undergraduateeducated teachers and master-educated teachers. This statement is based on the value shown in the equal variances assumed column, with a t statistic of 0.523 and a sig value of 0.479 meaning that in the achievement of teacher performance results there is no significant difference in the level of teacher education.

Both test results showed that differences in gender and level of education did not deliver significantly different results than performance achievements. This means that between male and female teachers in and level of education, in the implementation of their duties and responsibilities are not influenced by the profile attached to the teacher. These results also indicate that the role of female teachers outside of her duties as educators, does not have a real impact on performance achievement, nor on education. Between undergraduate and master teachers, it does not give results different from the point of view of performance achievement.

The gender and level of education of teachers as the results of the study do not make a difference in results to performance achievement. This means that the teacher's profile (gender and education) is not a factor that affects his performance during his or her time as an educator. Ideally, teachers with higher education should perform better, considering that mental aspects, gaping, knowledge, and skills are better compared to lower-educated teachers. This assumption also applies to the gender of teachers, female teachers with dual roles (as educators and housewives) should be in lower results than male teachers. This assumption is built on the availability of time. Male teachers generally have more time than female teachers, so they have more opportunities to develop themselves: participate in training and development, follow scientific studies, and other activities that can improve performance achievement.

The results of this study contradict the research conducted by Holmlund and Sund Stockholm, Sweden [6]. From the results of his research, it found that there are performance differences based on the gender of the subject's teachers, and this influence is considered causality to performance. This research is also supported by the results of a study find that in the context of teaching, female teachers are more likely to improve students' learning outcomes through the construction of a democratic learning environment [7]. Unlike male teachers who tend to be more prescriptive and traditional, it leads to masculine learning, which is less helpful as students' learning outcomes.

The true level of education is the basic capital for each individual to be able to work better, including on teachers. Higher education, opening up to wider and more complex access to information and knowledge, as well as more mature thinking construction compared to low-educated teachers. This capital is needed to address dynamic educational issues and requires innovation and creativity in its handling. So, it can be said that, with higher education allows teachers to be more mature and professional in carrying out their duties as educators. The findings of the study presented reinforce the statement of the study concerning this, that higher education graduates who walk the education level longer provide more performance results than teachers who only have an education for four years (undergraduate) [8].

Student achievement is very closely related to the profile of teachers, both in math, language, history and science subjects [9]. The profile of the teacher who determines this is certification, and the degree of education obtained, namely bachelor's and master's degree. Teacher quality is an important element in the development of students' potential. Students will develop optimally if supported by teachers with adequate knowledge transfer skills, experience, and maturity. In addition, teacher confidence levels are also an important factor, and this can be built through education. So it becomes important when talking to professional teachers, considering one of the conditions for realizing this kind of teacher is the level of education it obtains [10].

\section{CONCLUSION}

The results of the study concluded that gender and education levels do not differ in the results of teacher performance. These two aspects are important factors that are differentiating in the implementation of their duties as educators. Higher education ideally contributes to better performance achievement than teachers with lower education. Likewise, in male teachers, where roles and time allow to access supportive learning resources on competencies and better performance than female teachers who generally also act as housewives. The recommendation of this study is that there needs to be a more in-depth study of the impact of education on performance, especially in terms of the linearity of existing teacher education.

\section{REFERENCES}

[1] S. Siswandari and S. Susilaningsih, "Dampak Sertifikasi Guru terhadap Peningkatan Kualitas Pembelajaran Peserta Didik," J. Pendidik. dan Kebud., vol. 19, no. 4, pp. 487-498, 2013.

[2] M. R. Ramdhani, V. Hadiwiyono, and L. Hakim, "Dampak Sertifikasi Guru Terhadap Perilaku Sosial Dan Ekonomi Guru Di Kabupaten Ngawi Tahun 2016," Ekuitas (Jurnal Ekon. dan Keuangan), 2018.

[3] H. Heine, "Teacher Certification Systems. Policy Brief.," Pacific Resour. Educ. Learn., 2006.

[4] M. Mansur, "Sertifikasi Guru Menuju Profesionalisme Pendidik, Jakarta: PT," Bumi Aksara, 2007.

[5] J. Duffy, K. Warren, and M. Walsh, "Classroom interactions: Gender of teacher, gender of student, and classroom subject," Sex Roles, 2001.

[6] H. Holmlund and K. Sund, "Is the gender gap in school performance affected by the sex of the teacher?," Labour Econ., 2008.

[7] D. Madrid and S. P. Hughes, "Speaking the Same Language? GenderBased Teacher Performance in the EFL Class !2009-12-01 !2010-04 09 !2010-05-25 !," Open Appl. Linguist. J., 2010.

[8] M. D. Andrew and R. L. Schwab, "Has Reform in Teacher Education Influenced Teacher Performance? An Outcome Assessment of Graduates of an Eleven-University Consortium," Action Teach. Educ., 1995

[9] D. D. Goldhaber and D. J. Brewer, "Evaluating the effect of teacher degree level on educational performance," Dev. Sch. Financ., 1996.

[10] A. Leigh and S. Mead, "Lifting teacher performance," Policy Report. Washington, DC Progress. Policy Inst., 2005. 